\title{
Influence of salinity and suction on slope stability in transported material
}

\begin{abstract}
PM Dight Australian Centre for Geomechanics and The University of Western Australia, Australia
\end{abstract}
Q Hong The University of Western Australia, Australia

A Dyskin The University of Western Australia, Australia

E Pasternak The University of Western Australia, Australia

\begin{abstract}
Slope design in the regolith comprising weathered rock and transported materials is often very conservative. This arises from the use of conventional laboratory testing using saturated samples. In Western Australia, many of the mines are located in areas of high salinity. When materials recovered for testing are located above the water table they are most likely to be affected by suction. In this paper the authors will present the results of testing materials recovered from a gold mine where the in situ water content was approximately $20 \%$ while the saturated water content was approximately 50\%. The material had a permeability of approximately $10^{-10} \mathrm{~m} / \mathrm{s}$ and comprised over $40 \%$ clay size material. The salinity was approximately 7,000 ppm. Suction comprises matric and osmotic suction. The test work shows that the osmotic suction had the most significant effect on reducing the in situ water content and raising the shear strength parameters. This had a big impact on understanding of slope stability in these materials. The dispersive nature of the material subsequently influenced stability when approaching the ground water table but for unforeseen reasons. The paper shows how the slope was then stabilised.
\end{abstract}

\section{Introduction}

Many open pit mines in Western Australia are initially excavated in highly to completely weathered materials. These materials are often difficult to characterise as initial sampling is undertaken using reverse circulation drilling so there is no core to examine or test. When the material is sampled using diamond drilling the recovered material is disturbed by the process. This arises because the material is sodic (i.e. has high concentration of sodium $\left(\mathrm{Na}^{+}\right)$ions) and readily disperses in contact with water. If samples are recovered for testing, the most common approach is to determine the material properties using triaxial testing. The samples are typically saturated and tested using undrained/unconsolidated procedures. The theory of these tests is that no friction is recorded but this is rarely the case as the materials are not 'purely' clay. A consequence is the shear strength properties (cohesion and friction) are very low resulting in slope designs with flat angles (i.e. less than or equal to $25^{\circ}$ ).

However these weathered materials are generally situated above the surrounding groundwater table. Hence it is reasonable to assume that they could be subject to suction effects. If this is the case then the shear strength properties will be higher than the saturated material and the stable slope angle may be significantly steeper than could be achieved if saturated.

A major aspect of mining is to minimise the stripping ratio while managing the risk of instability arising from slope failure. As such, geotechnical engineers are pressed to develop what may be thought of as aggressive slope designs. Care must be taken to understand the risks involved in such designs, as failures may involve major infrastructure like pit access (e.g. haulroads), so taking an aggressive approach to slope design cannot be undertaken without significant geotechnical considerations.

How do designers investigate the influence of suction? There is an extensive body of literature which addresses the influence of suction using the soil water characteristic curve (SWCC). Starting with a saturated 
sample, the procedure is to subject the material to increasing levels of suction. At each level of suction (typically in the range $100 \mathrm{kPa}$ to $1,500 \mathrm{kPa}$ ), the water content of the material is determined once the sample moisture content reaches equilibrium. In this way the matric suction is determined. The SWCC works well with sandy to silty material. However as noted earlier many of the materials encountered in Western Australia are sodic (high $\mathrm{Na}^{+}$ions) which readily disperse when wet. Obtaining an undisturbed, saturated sample is extremely difficult. Thus one has to resort to remoulded samples which will affect the measured shear strength properties.

Another aspect is the clay content of the material. In transported materials found in the Australian palaeochannels, the clay content can be as high as $90 \%$. The higher the clay content the longer it takes for samples to reach equilibrium in the SWCC test. If the clay is also a smectite the situation is exacerbated.

If the material is located in a highly saline environment then the osmotic suction adds to the strength of the material.

So in Western Australia many mines are located in palaeochannels in highly saline environments with significant percentages of smectite (e.g. montmorillonite, illite, nontronite, and/or saponite) clays.

This paper will describe one such material and the effect of the suction on the shear strength parameters. It will show how the standard SWCC test was inappropriate for the material, and the profound influence of the salinity on the natural water content and the consequential effect on increasing the available shear strength. Very steep slopes can be achieved in unsaturated materials in these circumstances. It will show that careful consideration is needed when approaching the water table to limit any instability.

The paper will also present what occurred once the groundwater table was intersected and how this was subsequently managed.

\section{Site location}

Figure 1 shows how many mines in Western Australia are subject to the influence of salinity.

The location of the mine site is shown in Figure 2 and is located in a broad area of inferred salinity of $7,000 \mathrm{ppm}$.
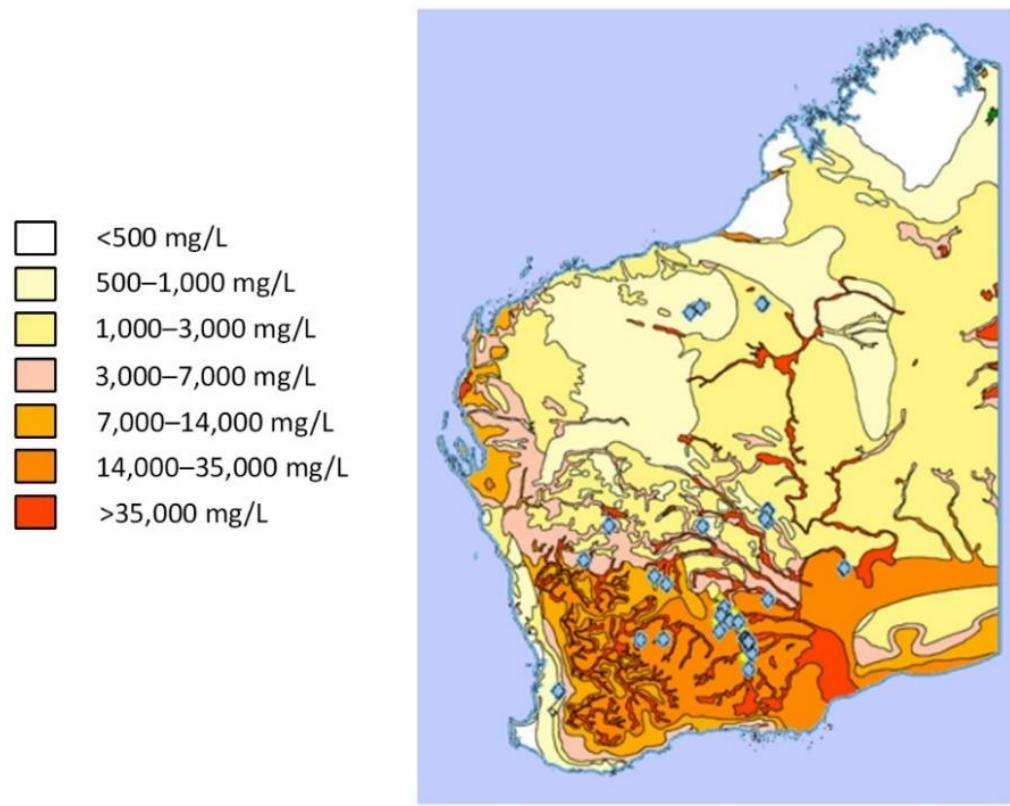

Figure 1 Operating gold mines and salinity distribution in Western Australia

The highest salt concentration is in the southwest of Western Australia where there are a number of operating mines (Figure 2). 


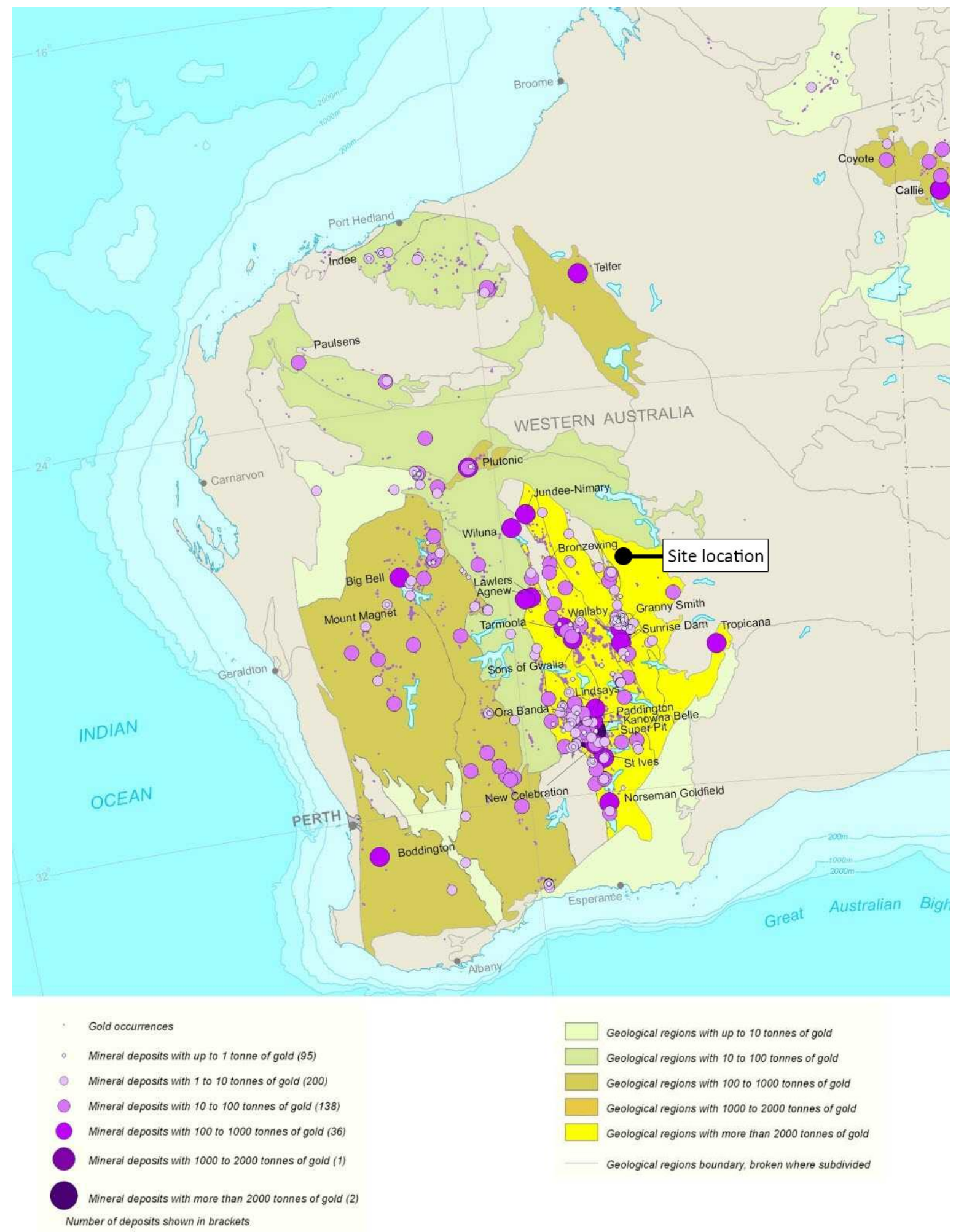

Figure 2 Gold occurrence in Western Australia map (O'Connor 2010)

\section{$3 \quad$ Material in its natural state}

At the test site, the material was recovered from the open pit (Figure 3) and it quickly dried out (Figure 4). The in situ or natural water content was approximately $20 \%$. In the laboratory the saturated water content was measured at approximately 56\%. A grading curve for the material is shown in Figure 5 and indicates that the clay content exceeds $90 \%$. The measured permeability of the material was $10^{-10} \mathrm{~m} / \mathrm{s}$. To put this in perspective it would take 320 years for water to travel $1 \mathrm{~m}$ in this material. 


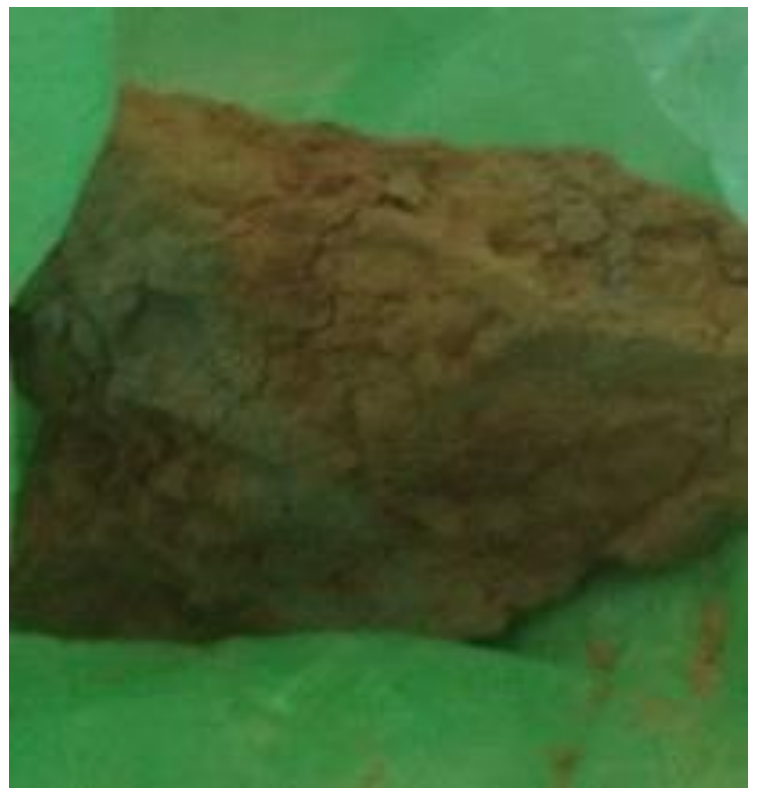

Figure 3 Whole block soil sample taken from the mine

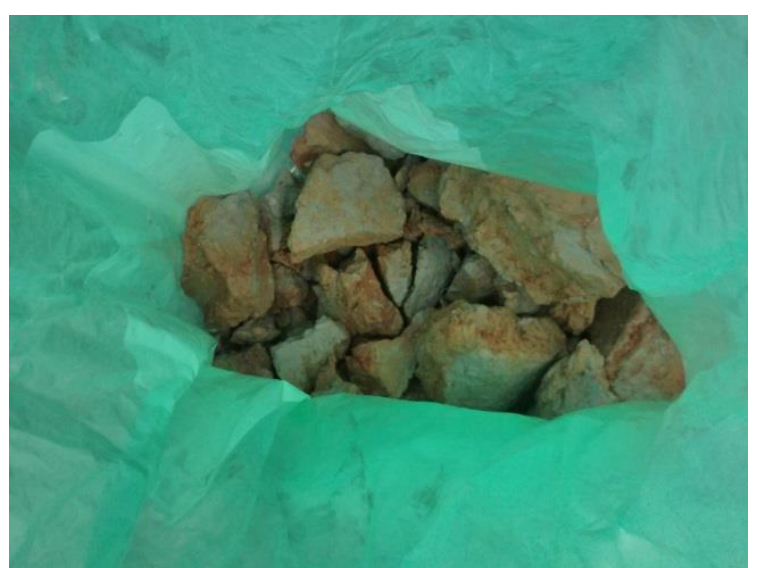

Figure 4 Crumbled soil sample taken from the mine

PSD: dispersive soils

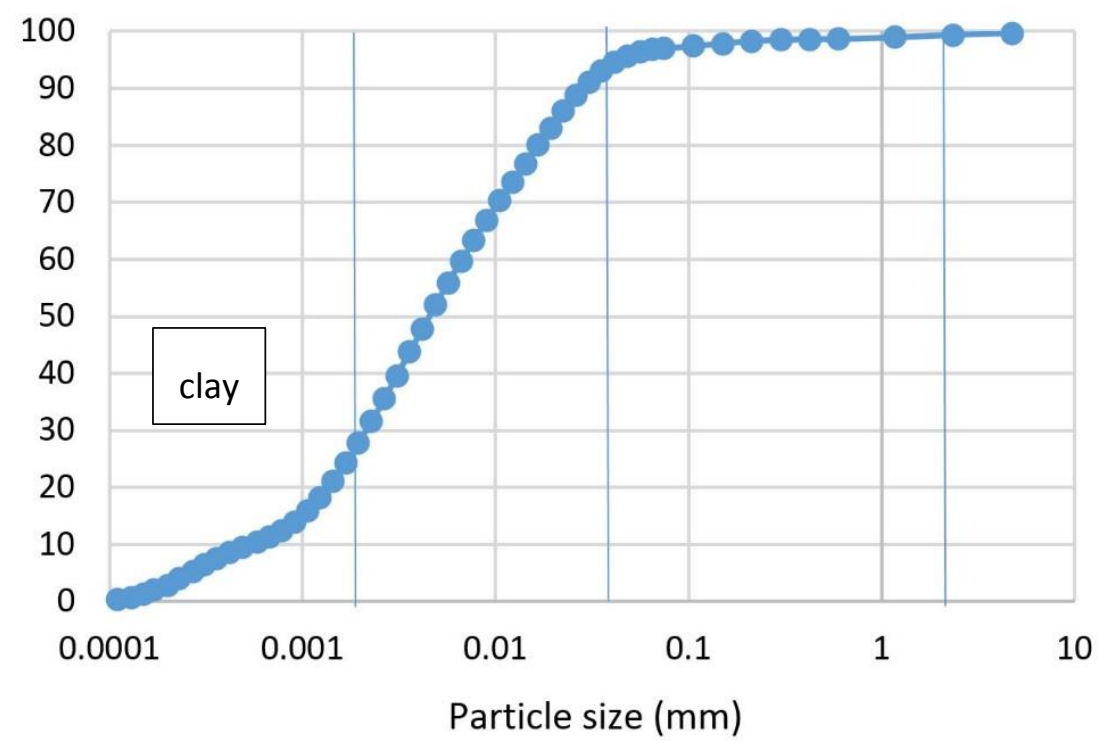

Figure 5 Plot of particle size distribution (PSD) 
As we can see in the particle size distribution (Figure 5) plot, $70 \%$ of the soil particles are finer than $0.01 \mathrm{~mm}$ and $97 \%$ of the particles have the size smaller than $0.1 \mathrm{~mm}$. This means the soil sample is well graded with a Uniformity Coefficient (D60/D10) of 11.4.

\section{$4 \quad$ Soil water characteristic curve tests}

The material was subject to a program of testing in the SWCC cell (Fredlund et al. 2011). This cell comprises a ceramic porous plate on which the sample to be tested is placed. The cell can be pressurised up to $1.5 \mathrm{MPa}$. At selected pressures (say 0.1, 0.5, 1.0 and $1.5 \mathrm{MPa}$ ) the change in water content can be measured after equilibrium is reached. These 2 parameters are then plotted to create the SWCC curve. It is particularly applicable to sandy and silty materials. The air entry level corresponds to a change in gradient of the curve after which water releases quickly. A similar point known as the water entry level occurs when the sample test procedure is reversed (known as the wetting cycle).

Some results are shown in Figures 6,7 and 8. At a suction of 1,200 kPa the water content had dropped from a saturated condition (56\%) to approximately $49 \%$ and is nowhere near the in situ water content of $20 \%$. The time taken to achieve the result in the SWCC cell was six months.

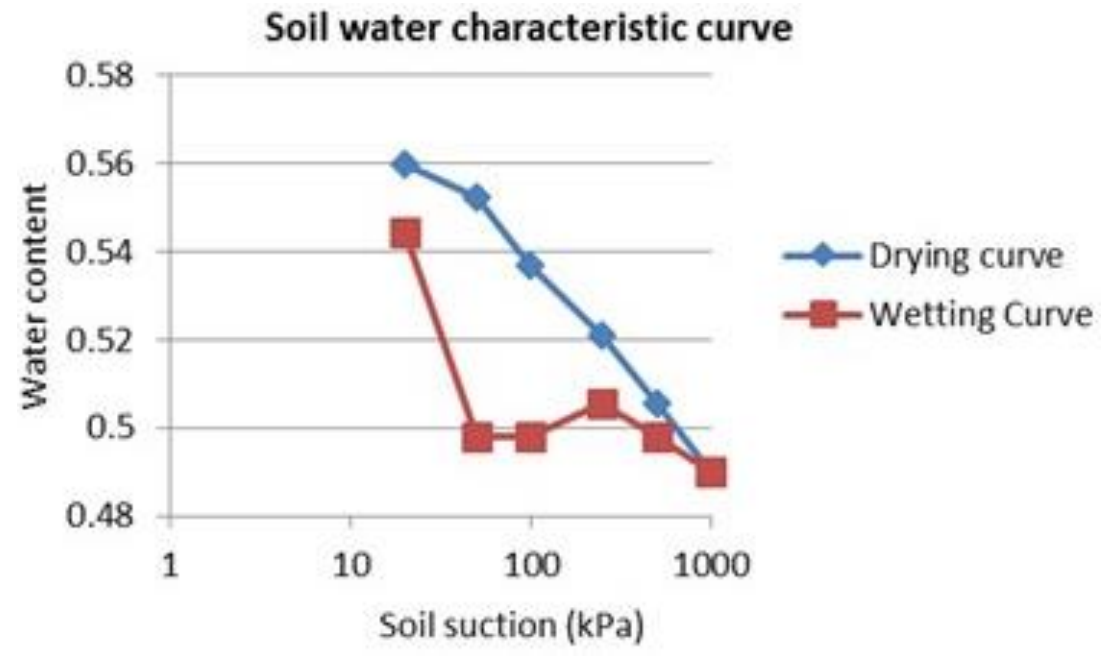

Figure 6 SWCC cyclic curve for soil suction test (remoulded sample 1)

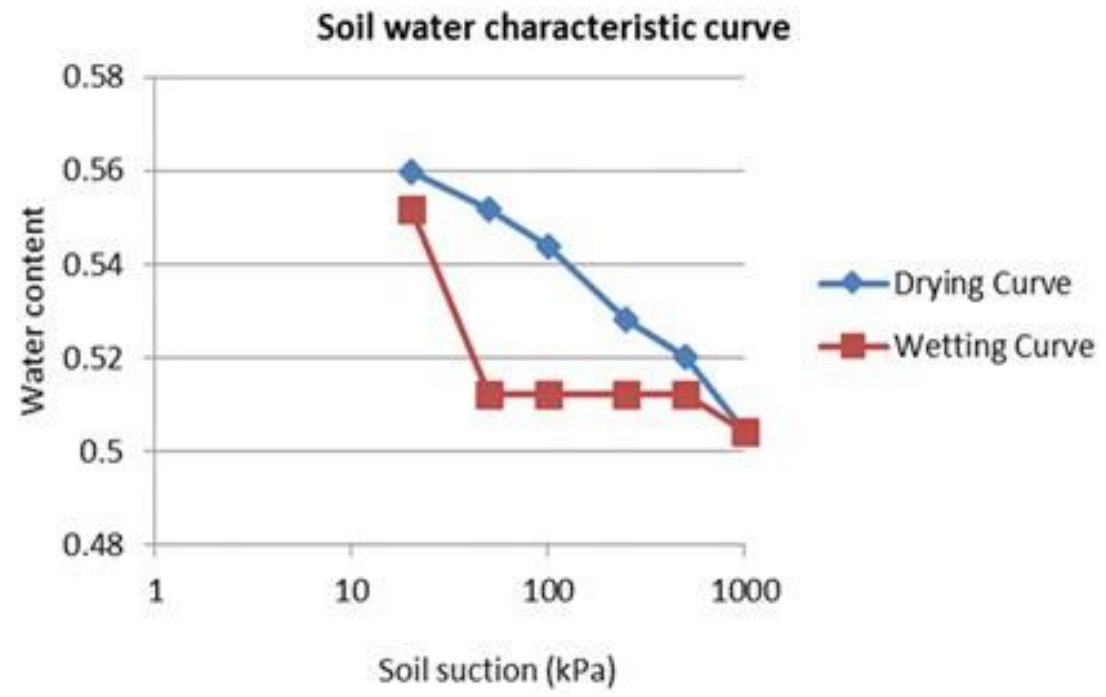

Figure 7 SWCC cyclic curve for soil suction test (remoulded sample 2) 


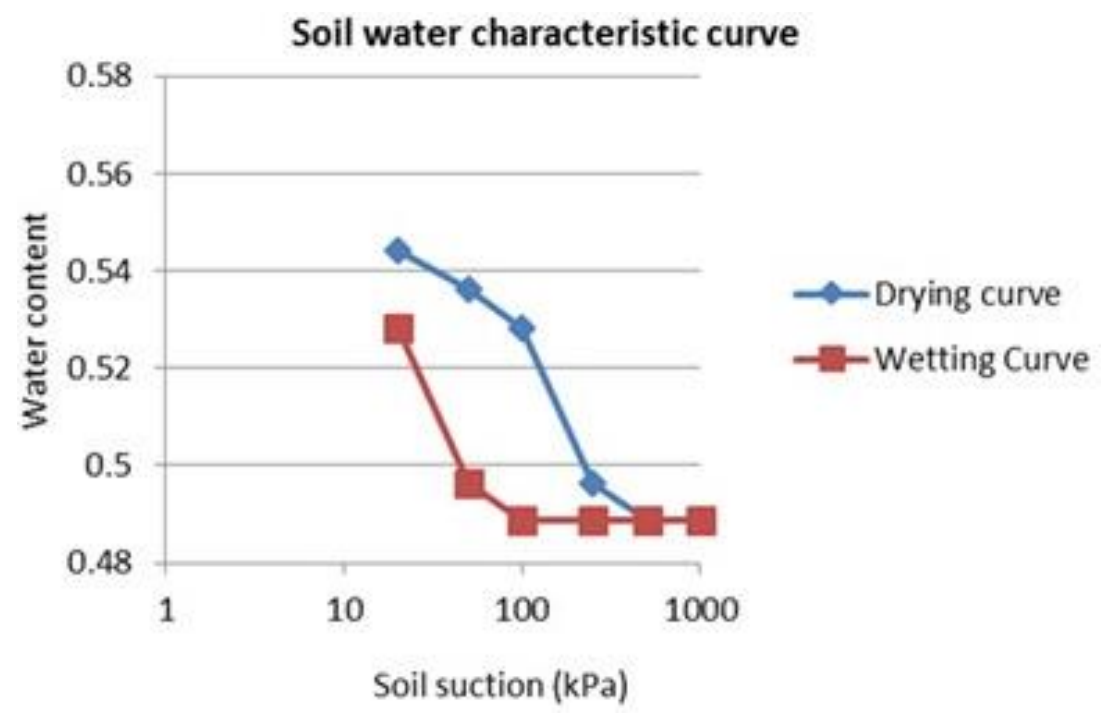

Figure 8 SWCC cyclic curve for soil suction test (remoulded sample 3)

The inflection points on the curve are critical points for they are used to determine both air entry value and water entry value.

\section{$5 \quad$ Influence of salinity}

Table 1 summarises typical salinities of ground water that can be experienced in mining while Table 2 shows what is meant by low, medium and high salinity levels. The nominal salinity at the mine site was $7 \mathrm{~g} / \mathrm{l}$ so would be termed a medium salinity.

Table 1 Water salinity based on dissolved salts (Wetzel 2001)

\begin{tabular}{cccc}
\hline Fresh water & Brackish water & Saline water & Brine \\
\hline$<0.05 \%$ & $0.05-3 \%$ & $3-5 \%$ & $>5 \%$ \\
\hline
\end{tabular}

Table 2 Salt concentration of the soil water

\begin{tabular}{ccc}
$\begin{array}{c}\text { Salt concentration of the soil water } \\
\text { (saturation extract) } \\
\text { in } \mathrm{g} / \mathrm{I}\end{array}$ & Salinity \\
\hline $0-3$ & $0-4.5$ & Non saline \\
(Conductance) & & \\
\hline $3-6$ & $4.5-9$ & Slightly saline \\
\hline $6-12$ & $9-18$ & Medium saline \\
\hline More than 12 & More than 18 & Highly saline \\
\hline
\end{tabular}

An osmotic suction can be generated in a soil by placing the soil over a saturated salt solution. As shown in Figure 9 a soil placed over a saturated sodium chloride solution can generate an osmotic suction of $38 \mathrm{MPa}$. 


\begin{tabular}{|c|c|c|c|c|}
\hline Salt Solution & $\begin{array}{l}\text { Temp. } \\
\left({ }^{\circ} \mathrm{C}\right)\end{array}$ & $\mathrm{RH}$ at $25^{\circ} \mathrm{C}$ & $\begin{array}{c}\mathrm{d}(\mathrm{RH}) / \mathrm{dT} \% /{ }^{\circ} \mathrm{C} \\
\text { from } 25^{\circ} \mathrm{C} \\
\end{array}$ & \multirow{11}{*}{$\begin{array}{l}\text { Osmotic } \\
\text { suction } \\
\text { based } \\
\text { on RH } \\
(\mathrm{MPa}) \\
@ 25^{\circ} \mathrm{C}\end{array}$} \\
\hline $\mathrm{NaOH} . \mathrm{H}_{2} \mathrm{O}$ & $15-25$ & 7.0 & 0 & \\
\hline $\mathrm{LiCl} . \mathrm{H}_{2} \mathrm{O}$ & $20-70$ & 11.3 & -0.01 & \\
\hline $\mathrm{MgCl}_{2} \cdot 6 \mathrm{H}_{2} \mathrm{O}$ & $10-50$ & 32.7 & -0.06 & \\
\hline $\mathrm{NaCl} .2 \mathrm{H}_{2} \mathrm{O}$ & $5-35$ & 39.2 & -0.32 & \\
\hline $\mathrm{KNO}_{2}$ & $20-40$ & 48.2 & -0.18 & \\
\hline $\mathrm{Mg}\left(\mathrm{NO}_{3}\right) \cdot 6 \mathrm{H}_{2} \mathrm{O}$ & $0-50$ & 52.8 & -0.29 & \\
\hline $\mathrm{Na}_{2} \mathrm{Cr}_{2} \mathrm{O}_{7} \cdot 2 \mathrm{H}_{2} \mathrm{O}$ & $0-50$ & 53.7 & -0.27 & \\
\hline $\mathrm{NaBr} .2 \mathrm{H}_{2} \mathrm{O}$ & $-10-35$ & 58.2 & -0.28 & \\
\hline $\mathrm{NaNO}_{2}$ & $20-40$ & 64.4 & -0.19 & \\
\hline مئ1 & 10 & so_4 & 0 & \\
\hline $\mathrm{NaCl}$ & $5-60$ & 75.1 & -0.02 & 38.6 \\
\hline $\begin{array}{l}\left(\mathrm{NH}_{4}\right)_{2} \mathrm{SO}_{4} \\
\mathrm{KCl}\end{array}$ & $\begin{array}{l}25-50 \\
5-40\end{array}$ & $\begin{array}{l}80.2 \\
84.2\end{array}$ & $\begin{array}{l}-0.07 \\
-0.16\end{array}$ & 23 \\
\hline $\mathrm{K}_{2} \mathrm{CrO}_{4}$ & $20-40$ & 86.5 & -0.06 & \\
\hline $\mathrm{BaCl}_{2} \cdot 2 \mathrm{H}_{2} \mathrm{O}$ & $5-60$ & 90.3 & -0.08 & \\
\hline$\left(\mathrm{NH}_{4}\right) \mathrm{H}_{2} \mathrm{PO}_{4}$ & $20-45$ & 92.7 & -0.12 & \\
\hline $\mathrm{K}_{2} \mathrm{SO}_{4}$ & $15-60$ & 97.0 & -0.05 & 4 \\
\hline $\mathrm{CuSO}_{4} \cdot 5 \mathrm{H}_{2} \mathrm{O}$ & $25-40$ & 97.2 & -0.05 & \\
\hline
\end{tabular}

Figure 9 Relative humidity and osmotic suction under different salt solution effect $\left(25^{\circ} \mathrm{C}\right)$

When the same sample above was tested over a saturated Na solution (which produces an osmotic suction of $38 \mathrm{MPa}$ ), the water content achieved was $22 \%$. This was very close to the in situ water content and highlighted the influence of groundwater salinity on the osmotic suction.

\section{Shear strength of transported material}

The shear strength of the transported material was tested at different water contents. As the water content reduces there is a significant increase in the cohesive strength as shown in Table 3.

Table 3 Calculated cohesive strength $(\mathrm{kPa})$ under different water contents and normal stress

\begin{tabular}{|c|c|c|c|c|c|}
\hline \multirow{2}{*}{$\begin{array}{c}\text { Water content } \\
\text { (\%) }\end{array}$} & \multicolumn{5}{|c|}{ Normal stress (kPa) } \\
\hline & 50 & 100 & 150 & 200 & 400 \\
\hline 47.7 & 11 & & & & \\
\hline 46.5 & & 18 & & & \\
\hline 45.4 & & & 27 & & \\
\hline 45 & 14 & & & & \\
\hline 39 & & 32 & & & \\
\hline 38.9 & & & & 40 & \\
\hline 35.6 & & & & & 76 \\
\hline 23.5 & & & & 303 & \\
\hline 17.2 & & & & & 969 \\
\hline
\end{tabular}


In the Table 3, it shows that as the water content reduces it has a significant effect on the cohesive strength of material as it varies from $11 \mathrm{kPa}(\mathrm{WC}=47.7 \%)$ to $969 \mathrm{kPa}$ (WC=17.2\%). This is an exponential increase in shear strength assuming the friction angle is approximately constant. On the other hand, the normal stress applied to the soil sample also had effect on the shear strength of the soil sample, however the influence was not as much as that of the water content. For instance, at a water content of $45 \%$, the cohesion increased from $14 \mathrm{kPa}$ (normal stress $=50 \mathrm{kPa}$ ) to $27 \mathrm{kPa}$ (normal stress=150 $\mathrm{kPa}$ ).

\section{$7 \quad$ Influence of shear strength on slope stability}

Once the shear strength of the transported material was determined it was obviously easy to show what slope angle can be achieved. The calculations used the Rocscience program Slide ${ }^{\circledR}$. The result is shown in Figures 10(a) and 10(b) for a slope height of $80 \mathrm{~m}$ and a slope angle of $45^{\circ}$.

The slope's Factor of Safety (FS) is defined by the formula: FS=shear strength/shear stress. In this case, the forces holding the material on the slope including friction and cohesion are larger than the shear stress caused by the soil weight, so the slope is considered safe; the slope is unlikely to fail in the unsaturated zone as shown below. This also has been observed in the field unless something interferes.

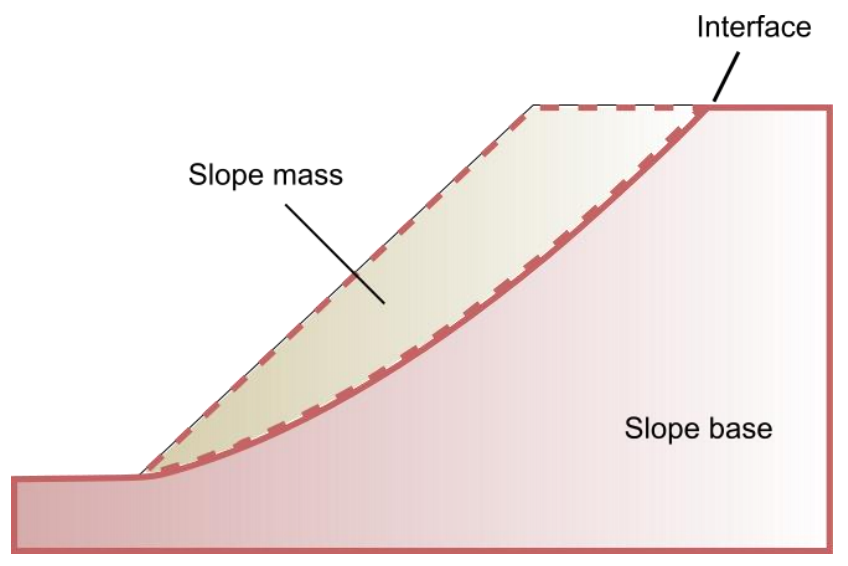

(a)

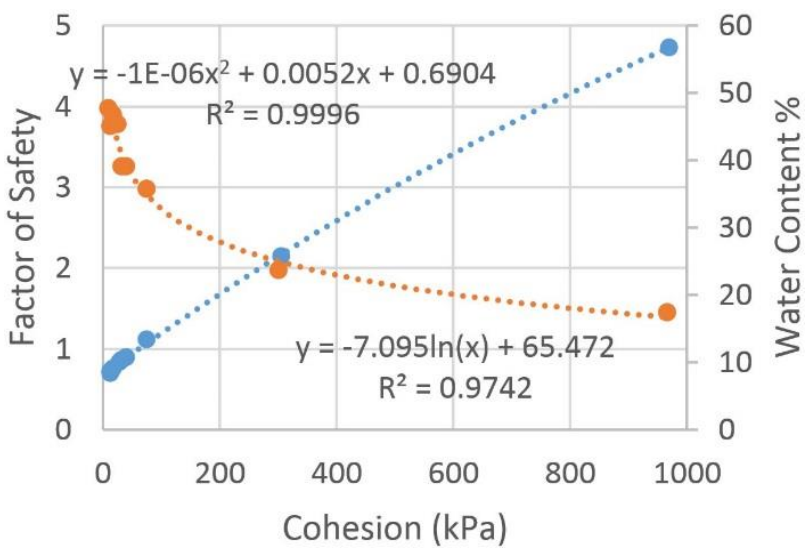

(b)

Figure 10 (a) Typical cross-section of a slope used in two-dimensional analyses; and (b) Factor of Safety increases with cohesion and with a drop in the natural water content due to suction

\section{Slope failure - our experience}

Notwithstanding the significant increase in the shear strength due to the matric and osmotic suction, the slope still experienced instability. Why?

As already mentioned the material is highly dispersive. This could have just been manifested in surface erosion, commonly seen in slopes in the gold fields and/or in waste dumps which have been top dressed with the weathered material. In this case however at the base of the transported material there was a very fine sand layer. The sand was saturated.

Slope failure initiated when the fine sand piped out from underneath the overlying transported material. Once undercut the overlying material slumped into the water thus dispersing. The resulting angle of the dispersed material was $15^{\circ}$. As this material 'oozed' the process was repeated until a significant portion of the overlying material had failed. Figure 11 shows a cartoon of the process. 


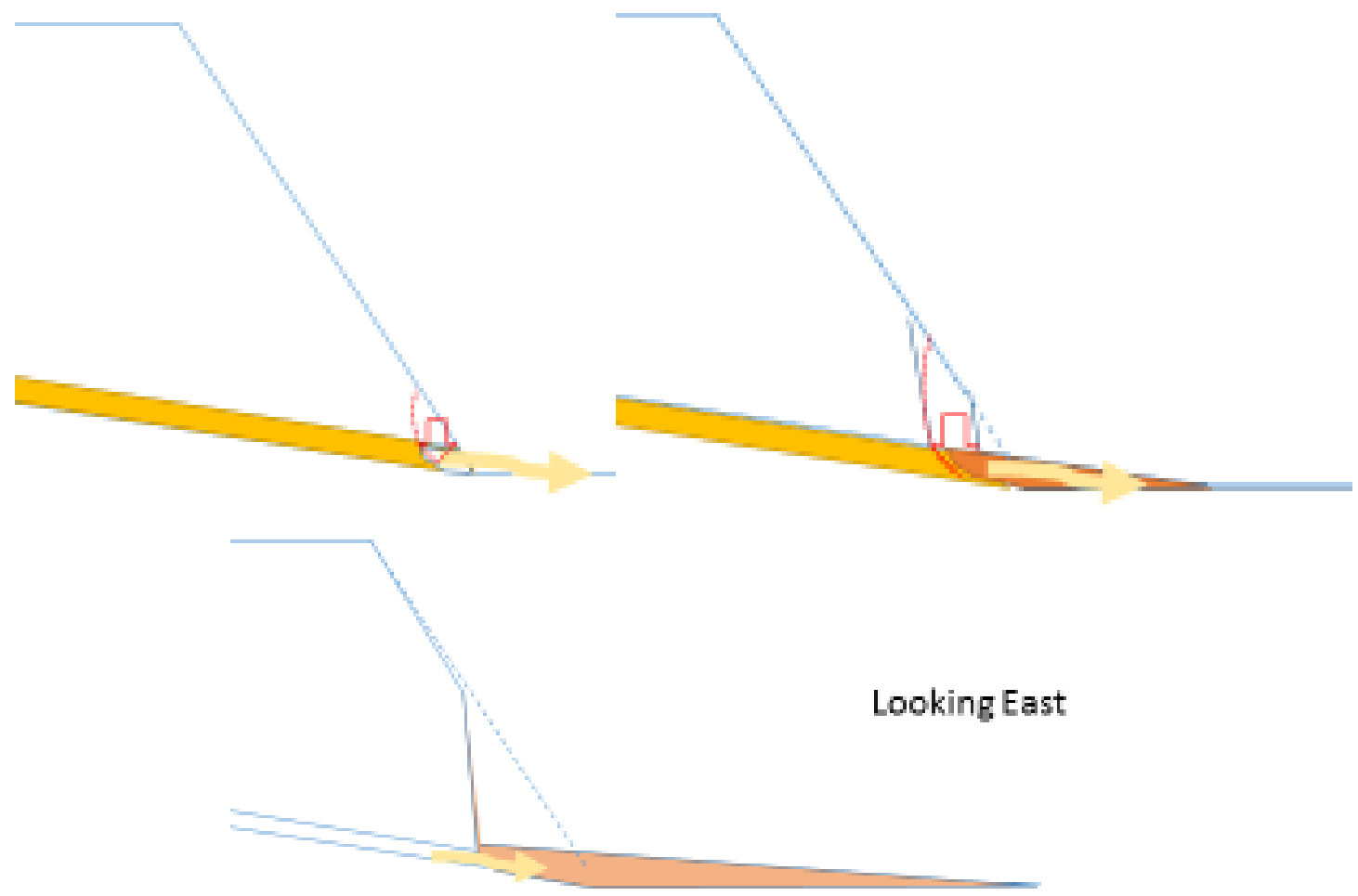

Figure 11 Piping of the fine sand undercut the slope. As the overlying material was dispersive, when it collapsed into the ponding water it rapidly became saturated. In a saturated state the slope angle was $8^{\circ}$

Figure 12 is a photograph of the failed slope showing the slumping progressively working back into the slope above.

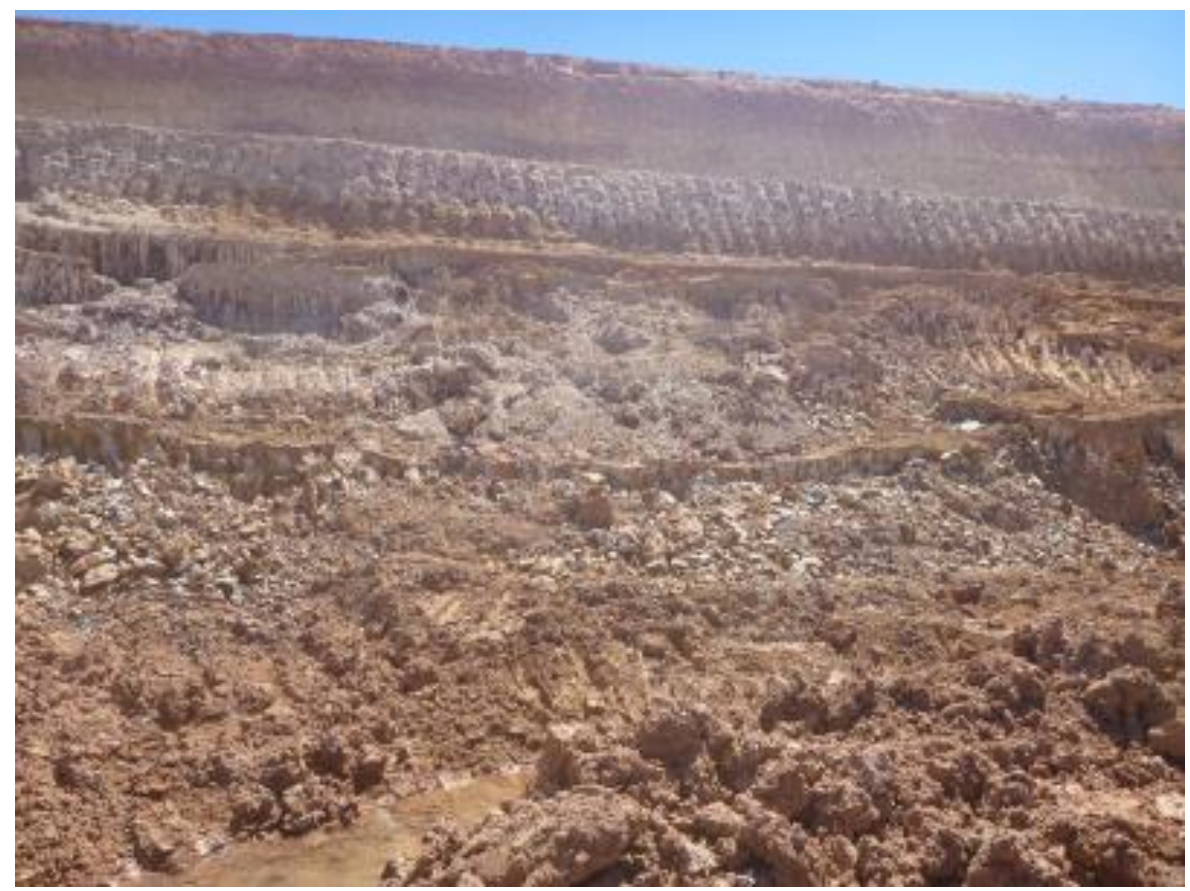

Figure 12 Photograph of slope failure 


\section{Remediation}

It would have been a simple approach to assume that the slope failure resembled a rotational failure due to saturation of the transported material. However on consideration of the actual mechanism, a better solution was to build a 'dam buttress' to contain the fine sand and prevent the mechanism from developing. An alternative would have been to develop a sand filter and drainage system.

This approach was adopted by the mine and success was achieved with a slope angle of $37^{\circ}$.

\section{Discussion}

In pits where the transported materials and weathered materials are dispersive, it is critically important not to locate in-pit sumps against these walls. Sometimes it is inadvertent that pits are subject to cyclonic rain and can be flooded. As a consequence sloughing failures must be expected until the pit can be dewatered. Hence due consideration in the risk management is to avoid such situations.

Depressuration holes should also be plumbed to remove water away from the walls for the same reasons.

There are significant savings to be made if suction can be taken into account when undertaking slope designs. These savings will be destroyed if these risk management approaches are ignored.

The SWCC approach is warranted to establish the influence of matric suction versus osmotic suction. It, however, is a long term test for very low permeability materials as encountered here and without adequate planning to allow for such testing, may be considered inappropriate for materials which have a very high clay content. In this study the effect of salinity is profound and the work here shows the way for achieving increased slope angles when appropriate operational procedures are followed.

\section{Summary}

Ignoring the influence of unsaturated soil behaviour in the Western Australian gold mines has resulted in very conservative designs. Moreover the influence of salinity in generating osmotic suction can significantly increase the material strength. This paper has highlighted the upside that could be achieved without resorting to unacceptable slope designs.

\section{Acknowledgement}

The authors are very appreciative of the support provided by Regis Resources and their personnel.

\section{References}

Fredlund, DG, Rahardjo, H \& Fredlund, MD 2011, Unsaturated Soil Mechanics in Engineering Practice, John Wiley \& Sons, Inc., p. 926. O'Connor, B 2010, Gold occurrence in Western Australia map, Gold Prospecting in Western Australia, viewed 6 July 2016, www.gold-prospecting-wa.com

Wetzel, RG 2001, Limnology: Lake and River Ecosystems, 3rd ed, Academic Press. 